\title{
The change in macroalgal assemblages through the Saldanha Bay / Langebaan Lagoon ecosystem (South Africa)
}

\author{
Schils T.' , O. De Clerck', F. Leliaert', J.J. Bolton ${ }^{2}$ and E. Coppejans' \\ 'University of Ghent, Department of Biology, Laboratory of Botany \\ K.L. Ledeganckstraat 35, B-9000 Ghent, Belgium \\ E-mail: tom.schils@rug.ac.be \\ ${ }^{2}$ University of Cape Town, Department of Botany \\ Rondebosch 7700, South Africa
}

The intertidal macroalgal assemblages of Saldanha Bay and Langebaan Lagoon were studied in relation to the relatively well known South African West Coast flora. Three distinct floral entities were identified using various analytical techniques: (i) the species poor, though distinct, salt marshes; (ii) the lagoon sites, and (iii) the bay and West Coast sites. The species richness of the bay/West Coast entity is larger than in the lagoon. The change in algal composition can be explained in terms of the environmental variables of which the wave exposure is the most significant one. Biogeographical affinities within the entire South African shoreline were determined for the different algal entities. The bay/West Coast entity harbours a typical West Coast flora, with some noticeable effects of uplift of subtidal species into the infralittoral fringe and morphological variation in less exposed areas. The algal flora of the lagoon is also dominated by West Coast species, but is typified by species characteristic of sheltered habitats, and with a number of species which otherwise only occur on the geographically distant South Coast. The algae from the salt marshes belong to species which occur widely in these sorts of habitats. 